\title{
An account on the taxonomy and molecular diversity of a marine rock-pool dweller, Tigriopus fulvus (Copepoda, Harpacticoida)
}

\section{Una revisión de la taxonomía y diversidad molecular de un habitante de las charcas litorales Tigriopus fulvus (Copepoda, Harpacticoida)}

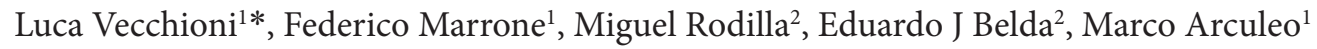 \\ ${ }^{1}$ Dipartimento di Scienze e Tecnologie Biologiche Chimiche e Farmaceutiche, Università degli Studi di \\ Palermo, via Archirafi, 18, I-90123 Palermo, Italy. \\ ${ }^{2}$ Research Institute for Integrated Management of Coastal Areas, Universitat Politècnica de València, \\ C/Paranimf, no. 1, E-46730, Gandía (Valencia), Spain.
}

* Corresponding author. E-mail: luca.vecchioni@unipa.it

\begin{abstract}
The copepod genus Tigriopus Norman, 1869 is distributed worldwide in coastal rock pools and it is currently considered to include 14 valid species. Tigriopus fulvus (Fischer 1860), with its subspecies Tigriopus fulvus adriaticus Van Douwe 1913 and Tigriopus fulvus algiricus Monard 1935, and Tigriopus minutus Bozic 1960 are currently reported to occur in the Mediterranean area, but the actual diversity of the genus is currently unknown. We aimed to assess the actual identity of Mediterranean Tigriopus populations and to elucidate their taxonomy and pattern of genetic diversity. In order to reach these goals, a fragment of a mitochondrial DNA gene (cytochrome c oxidase subunit I, COI) was sequenced to be used as a reference marker. Our data suggest the presence of a single species characterized by a noteworthy geographically based genetic structure in the whole study area. The observed diversity pattern is tentatively ascribed here to a strong monopolization of the rock pools by the first immigrants that reached them. However, such a monopolization is periodically disrupted by local extinction events, which are frequent in the intrinsically unstable rock pool habitats. We propose the name "clockwork monopolization" for this pattern.
\end{abstract}

Key words: genetic structuring, clockwork monopolization, rocky shore communities, cryptic species, DNA taxonomy.

RESUMEN. El género de copépodos Tigriopus Norman, 1869 se distribuye en todo el mundo en charcas de rocas costeras y se considera que actualmente incluye 14 especies válidas. Tigriopus fulvus (Fischer 1860), con sus subespecies Tigriopus fulvus adriaticus Van Douwe 1913 y Tigriopus fulvus algiricus Monard 1935, y Tigriopus minutus Bozic 1960 han sido descritos para el área del Mediterráneo, pero la diversidad real del género es desconocida actualmente. El objetivo de este estudio fue evaluar la identidad real de las poblaciones mediterráneas de Tigriopus y dilucidar su taxonomía y patrón de diversidad genética. Con este fin, se secuenció un fragmento del gen de ADN mitocondrial (citocromo c oxidasa subunidad I, COI) como marcador de referencia. Los resultados sugieren la presencia de una sola especie caracterizada por una estructuración genética con una notable base geográfica en toda el área de estudio. El patrón de diversidad observado aquí se atribuye tentativamente a una fuerte monopolización de las charcas de las costas rocosas por parte de los primeros inmigrantes que las alcanzan. Sin embargo, tal monopolización se interrumpe periódicamente por los eventos de extinción local, los cuales son frecuentes en los hábitats de charcas de rocas que son intrínsecamente inestables. Aquí proponemos para este patrón el nombre de "monopolización periódica" (“clockwork monopolization”).

Palabas clave: estructuración genética, monopolización periódica, comunidades de costas rocosas, especies crípticas, taxonomía basada en ADN.

\section{INTRODUCTION}

Tigriopus Norman, 1869 is a copepod genus typically linked to marine rock pools in the supratidal and the uppermost intertidal zones (McAllen 1999), although it is also known to occur subtidally off the Antarctic Peninsula (Waller et al. 2006, Park et al. 2014), Mexico (Ganz and Burton 1995, Edmands 2001), Southern Asia (Jung et al. 2006, Ki et al. 2009), and Sweden (Lang 1948). The supratidal and intertidal coastal rock pools are harsh habitats characterized by the large instability of physical (e.g., temperature or water amount) and chemical conditions (e.g., oxygen content, $\mathrm{pH}$, salinity) (Ganning and Wulff 1970, Underwood and

\section{INTRODUCCIÓN}

Tigriopus Norman, 1869 es un género de copépodos típicamente vinculado a las charcas que se forman en las zonas de rocas en las zonas supramareales y partes superiores del área intermareal (McAllen 1999), aunque también se sabe que ocurre de manera submareal frente a la península Antártica (Waller et al. 2006, Park et al. 2014), México (Ganz y Burton 1995, Edmands 2001), Asia meridional (Jung et al. 2006, Ki et al. 2009) y Suecia (Lang 1948). Las charcas de roca costeras en las zonas supramareales e intermareales son hábitats hostiles caracterizados por una gran inestabilidad de las condiciones físicas (por ejemplo, la temperatura o la cantidad 
Skilleter 1996). To cope with such continuously changing habitats, behavioral andlor physiological mechanisms aimed at avoiding or overcoming adverse conditions were developed by the rock-pool-inhabiting fauna, which thus became a focal point for studies of these extreme environments (Dethier 1980, Raisuddin et al. 2007).

Like some species of the beetle family Hydraenidae (Antonini et al. 2010) and mosquitoes of the family Culicidae (Mastrantonio et al. 2015) occurring in the same habitat type, Tigriopus developed adaptations to survive these stresses. Adult beetles and mosquitoes are able to fly away from drying pools, switching to nearby filled pools, and in other taxa, late instar larvae can enter into resting stages, or resistant eggs might be produced (Williams 2007). Conversely, Tigriopus spp. survive desiccation as adults in a dormant state (Battaglia 1982) and are not able to produce resistant cysts or diapausing eggs. Moreover, adult Tigriopus californicus may persist in dried pools for some days or weeks, even without entering the "dormancy phase", retaining themselves in small habitable habitat patches awaiting better conditions to recolonize the same rock pool (Powlik 1998). The means of dispersal of Tigriopus spp. are still unknown, although the passive dispersal of the species mediated by birds, floating algae, and water currents has been proposed (see discussion in Handschumacher et al. 2010)

The genus Tigriopus includes 14 species (Walter and Boxshall 2018), and the following are known to occur in the Atlantic-Mediterranean area: Tigriopus brevicornis (Müller 1776) and Tigriopus brachydactylus (Candeias 1959) from Africa, Tigriopus fulvus (Fischer 1860) from the Mediterranean Sea and the Atlantic island of Madeira, and Tigriopus minutus Bozic 1960 from Senegal; this last species has also been dubitatively reported to occur in the Mediterranean Sea by Lazaretto and Libertini (1986), although no other records of T. minutus are available for this area. The species occurring in the Atlantic-Mediterranean area can be morphologically distinguished based on a few characters whose intra- and interspecific variability has not been exhaustively examined to date, and $T$. brevicornis was not recognized as taxonomically distinct from $T$. fulvus until the late 1970s (Carli and Fiori 1977). Moreover, in the early XX century, 2 "varieties" of T. fulvus were described, i.e., T. fulvus var. adriatica by Van Douwe (1913) from specimens collected in Rovinj (Croatia) and T. fulvus var. algirica by Monard (1935) from specimens collected in Tipasa (currently Tipaza, Algeria); oddly, these taxa were characterized based on a morphological comparison of these populations with the Atlantic species T. brevicornis instead of with T. fulvus s.s. (Carli and Fiori 1977). According to article 45.6.4 of the International Code of Zoological Nomenclature (https://www.iczn.org/), if a taxon of infrasubspecific rank was established before 1961, it has to be considered of subspecific rank (ICZN 1999); accordingly, T. fulvus is currently to be considered a polytypic de agua) y químicas (por ejemplo, el contenido de oxígeno, pH, salinidad) (Ganning y Wulff 1970, Underwood y Skilleter 1996). Para hacer frente a estos hábitats en constante cambio, la fauna que habita en las charcas de roca desarrolló mecanismos de comportamiento y/o fisiológicos destinados a evitar o superar condiciones adversas, lo que se convirtió así en un punto focal para los estudios de estos ambientes extremos (Dethier 1980, Raisuddin et al. al. 2007).

$\mathrm{Al}$ igual que algunas especies de escarabajos de la familia Hydraenidae (Antonini et al. 2010) y mosquitos de la familia Culicidae (Mastrantonio et al. 2015) que aparecen en el mismo tipo de hábitat, Tigriopus desarrolló adaptaciones para sobrevivir a estas tensiones. Los escarabajos adultos y los mosquitos pueden volar y escapar de las charcas que se están secando a otras charcas llenas cercanas y, en otros taxones, las larvas de estadios tardíos pueden entrar en las etapas de reposo, o pueden producirse huevos resistentes (Williams 2007). Por el contrario, Tigriopus spp. sobreviven a la desecación cuando son adultos en un estado latente (Battaglia 1982), y no pueden producir quistes de resistencia ni huevos de diapausa. Además, se ha observado que los adultos de Tigriopus californicus pueden sobrevivir en charcas secas durante algunos días o semanas, incluso sin entrar en "fase de latencia", manteniéndose en pequeños parches de hábitat habitables esperando mejores condiciones para recolonizar la misma charca de roca (Powlik 1998). Hasta la fecha, se desconocen los mecanismos de dispersión de Tigriopus spp., aunque se ha propuesto que es por dispersión pasiva mediada por aves, algas flotantes y corrientes de agua (ver discusión en Handschumacher et al. 2010).

El género Tigriopus incluye 14 especies (Walter y Boxshall 2018), y se sabe que las siguientes ocurren en el área del Atlántico-Mediterráneo: Tigriopus brevicornis (Müller 1776) y Tigriopus brachydactylus (Candeias 1959) en África, T. fulvus (Fischer 1860) en el mar Mediterráneo y la isla atlántica de Madeira, y Tigriopus minutus (Bozic 1960) en Senegal. Para esta última especie, Lazaretto y Libertini (1986) reportaron su ocurrencia en el mar Mediterráneo, aunque de manera dubitativa ya que hasta la fecha no hay otros registros de T. minutus disponibles para esta área. Las especies que se encuentran en el área atlántico-mediterránea pueden distinguirse morfológicamente en función de unos pocos caracteres cuya variabilidad intraespecífica e interespecífica no se ha examinado exhaustivamente hasta la fecha, y solo hasta finales de la década de los setenta, T. brevicornis fue reconocida como taxonómicamente distinta de T. fulvus (Carli y Fiori 1977). Además, a principios del siglo XX, se describieron 2 "variedades" de T. fulvus, es decir, T. fulvus var. adriatica por Van Douwe (1913) a partir de especímenes recolectados en Rovinj (Croacia) y T. fulvus var. algirica por Monard (1935) a partir de especímenes recolectados en "Tipasa" (actualmente Tipaza, Argelia). Curiosamente, estos taxones se caracterizaron con base en una comparación morfológica de estas poblaciones con la especie del Atlántico T. brevicornis en lugar de con T. fulvus s.s. (Carli y Fiori 1977). Según el 
species including the 3 subspecies Tigriopus fulvus fulvus (Fischer 1860), Tigriopus fulvus algiricus Monard 1935, and Tigriopus fulvus adriaticus Van Douwe 1913. As stressed by Lazzaretto and Libertini (1986), the actual genetic diversity pattern of Mediterranean Tigriopus populations is still unknown and yet to be properly explored.

In light of the paucity of data currently available, and of the taxonomic uncertainties affecting the genus Tigriopus in the Mediterranean area, the goal of this work is to explore the genetic variability of $T$. fulvus and its alleged subspecies along the coasts of the Mediterranean Sea, and to contribute to the clarification of their taxonomy. Moreover, we aimed to evaluate if the noteworthy interpopulation genetic diversity observed in several Mediterranean rock-pool-inhabiting taxa (e.g., Antonini et al. 2010, Audiso et al. 2010, Mastrantonio et al. 2015) also characterizes the harpacticoid copepods of the genus Tigriopus.

\section{MATERIALS AND METHODS}

In order to investigate the genetic diversity occurring among T. fulvus populations, copepods were collected from intertidal and supratidal rock pools in 21 different locations across the Mediterranean Sea and the eastern Atlantic Ocean (Table 1, Fig. 1). In addition, specimens of the North Atlantic species, T. brevicornis, were collected in Galicia (Spain) to be used as outgroup. Latitude and longitude for each locality was determined with a geographical positioning system (GPS). The map of the sampling sites was done using QGIS software v. 2.18.2 (http://www.qgis.org).

Harpacticoids were sampled with a $200-\mu \mathrm{m}$ mesh hand net. Collected specimens were fixed in situ in $96 \%$ ethanol, sorted out under a stereomicroscope and identified according to Wells (2007). In an attempt to identify the alleged T. fulvus subspecies, the identification keys provided by Monard (1935) and Van Douwe (1913) were used.

After morphological identification, specimens were dipped in double distilled water for $15 \mathrm{~min}$ and processed for DNA extraction using the BIORON GmbH Ron's Tissue DNA Mini Kit following the manufacturer's instructions. The selective amplification of a cytochrome $\mathrm{c}$ oxidase subunit I (COI) fragment was carried out by the polymerase chain reaction (PCR) using the primers L1384-COI and H2612-COI (Machida et al. 2004).

The PCR mix consisted of $18.05 \mu \mathrm{L}$ double-distilled water, $2.5 \mu \mathrm{L}$ Buffer $10 \mathrm{X}$ including $15 \mathrm{mM} \mathrm{MgC}_{12}$ solution, $0.25 \mu \mathrm{L}$ dNTPs (10 mM of each), $0.9 \mu \mathrm{L}$ of each primer $(10 \mu \mathrm{M}), 0.4 \mu \mathrm{L}$ BIORON DFS-Taq DNA Polymerase $5 \mathrm{U} / \mu \mathrm{L}$, and $2 \mu \mathrm{L}$ of DNA template, for a total volume of $25 \mu \mathrm{L}$. The thermal cycle consisted of 35 cycles of denaturing $\left(95^{\circ} \mathrm{C}\right.$ for $\left.50 \mathrm{~s}\right)$, annealing $\left(48^{\circ} \mathrm{C}\right.$ for $50 \mathrm{~s}$ ), and extension $\left(72{ }^{\circ} \mathrm{C}\right.$ for $\left.50 \mathrm{~s}\right)$, followed by $7 \mathrm{~min}$ at $72{ }^{\circ} \mathrm{C}$ for the final extension step. After PCR, $5 \mu \mathrm{L}$ of each PCR product were separated by electrophoresis on a artículo 45.6.4 del Código Internacional de Nomenclatura Zoológica (https://www.iczn.org/), si un taxón de rango infraespecífico se estableció antes de 1961, debe considerarse de rango subespecífico; en consecuencia, T. fulvus se considera actualmente una especie politípica que incluye las 3 subespecies Tigriopus fulvus fulvus (Fischer 1860), Tigriopus fulvus algiricus Monard 1935 y Tigriopus fulvus adriaticus Van Douwe 1913. Como subrayaron Lazzaretto y Libertini (1986), el patrón real de la diversidad genética de las poblaciones mediterráneas de Tigriopus es hasta la fecha desconocido y debe ser explorado adecuadamente.

En vista de la escasez de datos actualmente disponibles y de las incertidumbres taxonómicas que afectan al género Tigriopus en el área del mar Mediterráneo, el objetivo de este trabajo es explorar la variabilidad genética de T. fulvus y sus supuestas subespecies a lo largo de las costas del mar Mediterráneo, y contribuir a clarificar su taxonomía. Además, también se evaluó si la notable diversidad genética interpoblacional observada en diversos taxones que habitan las charcas de rocas en el mediterráneo (e.g., Antonini et al. 2010, Audiso et al. 2010, Mastrantonio et al. 2015) también caracteriza a los copépodos harpacticoides del género Tigriopus.

\section{MATERIALES Y MÉTODOS}

Para investigar la diversidad genética que se produce entre las poblaciones de $T$. fulvus, se recolectaron copépodos de charcas de rocas intermareales y supramareales de 21 lugares diferentes a lo largo del mar Mediterráneo y el océano Atlántico oriental (Tabla 1, Fig. 1). Además, los especímenes de la especie del Atlántico Norte T. brevicornis se recolectaron en Galicia (España) para ser utilizados como un grupo externo. La latitud y la longitud para cada localidad se determinaron con un sistema de posicionamiento global (GPS, por sus siglas en inglés). El mapa de los sitios de muestreo se realizó utilizando el software QGIS v.2.18.2 (http://www.qgis.org).

Para muestrear los harpacticoides utilizamos una red de mano con una luz de malla de $200 \mu \mathrm{m}$. Las muestras recolectadas se fijaron in situ con etanol al 96\%, se clasificaron bajo un estereomicroscopio y se identificaron según Wells (2007). En un intento por identificar las supuestas subespecies de T. fulvus, se utilizaron las claves de identificación proporcionadas por Monard (1935) y Van Douwe (1913).

Tras la identificación morfológica, las muestras se sumergieron en agua bidestilada durante $15 \min$ y se procesaron para la extracción de ADN utilizando el Ron's Tissue DNA Mini Kit de BIORON GmbH siguiendo las instrucciones del fabricantfe. La amplificación selectiva de un fragmento de la citocromo c oxidasa subunidad I (COI) se llevó a cabo mediante la reacción en cadena de la polimerasa (RCP) utilizando los cebadores L1384-COI y H2612-COI (Machida et al. 2004).

La mezcla para la RCP consistió en $18.05 \mu \mathrm{L}$ de agua bidestilada, $2.5 \mu \mathrm{L}$ de tampón $10 \mathrm{X}$ que incluyó una 
Table 1. Origin and GenBank accession numbers (A.N.) for the analyzed Tigriopus specimens. Geographic coordinates are expressed as decimal degrees (Map Datum: WGS84). *: specimens from the type locality of Tigriopus fulvus algiricus; §: specimen from the type locality of Tigriopus fulvus adriaticus; ${ }^{\dagger}$ : specimens from Madeira, the type locality of Tigriopus fulvus s.s.

Tabla 1. Origen y números de acceso (A.N.) a GenBank de los especímenes analizados. Las coordenadas geográficas se expresan como grados decimales (Datum del mapa: WGS84). *: especímenes de la localidad tipo de Tigriopus fulvus algiricus; §: ejemplar de la localidad tipo de Tigriopus fulvus adriaticus; ${ }^{\dagger}$ : especímenes de Madeira, la localidad tipo de Tigriopus fulvus s.s.

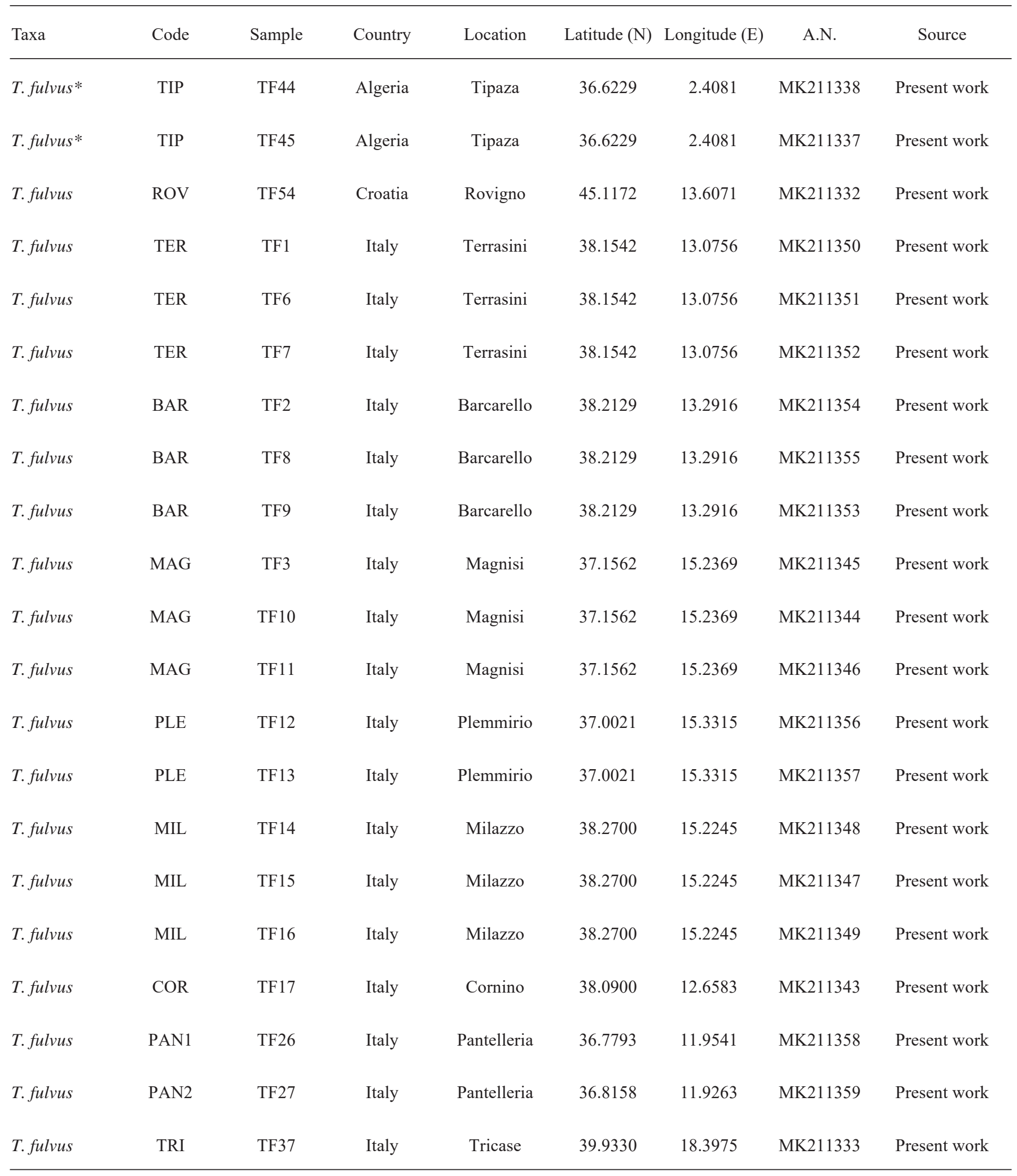


Table 1 (Cont.)

\begin{tabular}{|c|c|c|c|c|c|c|c|c|}
\hline T. fulvus & CEF & TF38 & Italy & Cefalù & 38.0415 & 14.0218 & MK211342 & Present work \\
\hline T. fulvus & CEF & TF39 & Italy & Cefalù & 38.0415 & 14.0218 & MK211341 & Present work \\
\hline T. fulvus & POR & TF43 & Italy & Portoscuso & 39.2065 & 8.3763 & MK211362 & Present work \\
\hline T. fulvus & CAS & TF46 & Italy & Castiglioncello & 43.4012 & 10.4045 & MK211339 & Present work \\
\hline T. fulvus & SDI & TF85 & Morocco & Sidi Ifni & 29.3467 & -10.1961 & MK211329 & Present work \\
\hline T. fulvus & CAT & TF87 & Morocco & Cape Tamry & 30.5465 & -9.7180 & MK211330 & Present work \\
\hline T. fulvus ${ }^{\dagger}$ & SXL & TF58 & Portugal & Seixal & 32.8270 & -17.1145 & MK211326 & Present work \\
\hline T. fulvus ${ }^{\dagger}$ & SXL & TF59 & Portugal & Seixal & 32.8270 & -17.1145 & MK211325 & Present work \\
\hline T. fulvus & JAV & TF49 & Spain & Jàvea & 38.7635 & 0.2050 & MK211336 & Present work \\
\hline T. fulvus & JAV & TF50 & Spain & Jàvea & 38.7635 & 0.2050 & MK211335 & Present work \\
\hline T. fulvus & BEN & TF52 & Spain & Benitachell & 38.7080 & 0.1664 & MK211334 & Present work \\
\hline T. fulvus & MEN & TF78 & Spain & Menorca & 39.9980 & 3.8274 & MK211360 & Present work \\
\hline T. fulvus & - & - & France & $\begin{array}{c}\text { Banylus Sur } \\
\text { Mer }\end{array}$ & 42.4833 & 3.1333 & AF315361 & Edmands 2001 \\
\hline T. fulvus & - & - & Spain & Blanes & 41.6666 & 2.8000 & AF315364 & Edmands 2001 \\
\hline T. brevicornis & GLC & TF79 & Spain & Sanxenxo & 42.3898 & -8.7767 & MK211363 & Present work \\
\hline T. brevicornis & GLC & TF81 & Spain & Sanxenxo & 42.3898 & -8.7767 & MK211364 & Present work \\
\hline
\end{tabular}




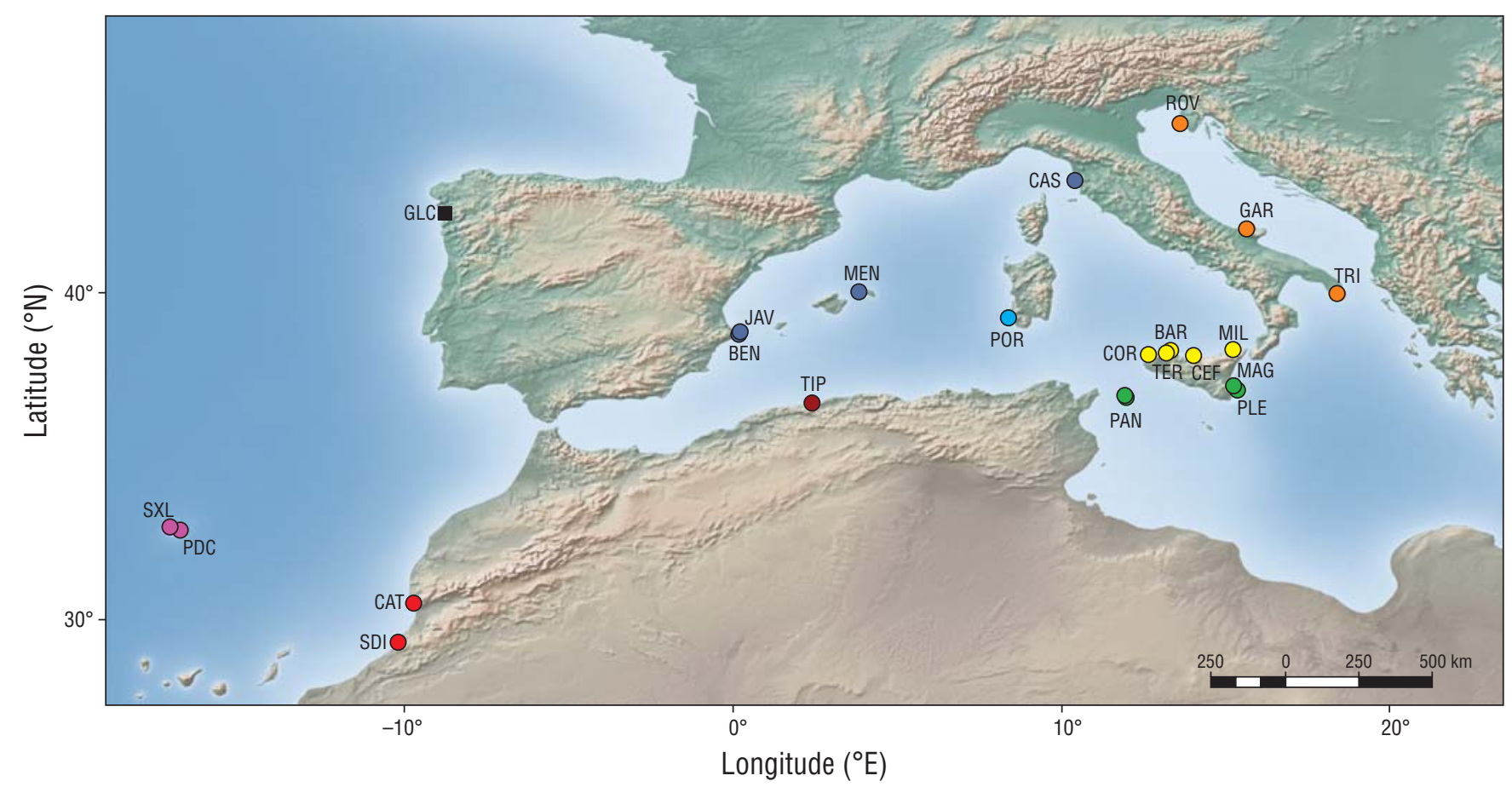

Figure 1. Geographic location of the sampling sites. Circles indicate sites where Tigriopus fulvus was sampled and square indicates sampling site for Tigriopus brevicornis. See Table 1 for the coordinates of the sampling sites and for more information on the collected species. Codes refer to those listed in Table 1. Color codes refer to those reported in Figure 2.

Figura 1. Localización geográfica de los lugares de muestreo. Los círculos indican puntos de muestreo para Tigriopus fulvus, y el cuadrado indica el punto de muestreo para Tigriopus brevicornis. Véase la Tabla 1 para las coordenadas de los sitios de muestreo, así como para más información sobre las especies recolectadas. Los códigos se refieren a los indicados en la Tabla 1. Los códigos de colores hacen referencia a la Figura 2.

$2 \%$ agarose gel at $90 \mathrm{~V}$ for $20 \mathrm{~min}$ and visualized with a UV Transilluminator. When PCR products showed a clear and single band of the expected length, they were purified using the Exo-SAP-IT kit (Affymetrix USB) and sequenced by Macrogen Inc. (Seoul, South Korea) with an ABI 3130xL (Applied Biosystems) sequencer. The same primers used for the PCR were subsequently used for direct sequencing of the PCR product, and the quality of the obtained chromatograms was checked through the measurement of their Phred scores (Richterich 1998). Only sequences with continuous reads of high-quality bases $(\mathrm{QV}>20)$ were used. Chromatograms were analyzed and manually proofread with the software Chromas v.2.6.2 (Technelysium, Pty. Ltd. 1998; Queensland, Australia) and aligned with ClustalX v.2.1 (Larkin et al. 2007).

The 39 novel mitochondrial sequences for T. fulvus and the 2 for T. brevicornis were deposited in GenBank (see Table 1 for their accession numbers). In addition, the only 2 T. fulvus sequences available on GenBank were downloaded and included in the analyses (see Table 1 for their accession numbers).

MEGA v.7.0 (Kumar et al. 2016) was used to translate the mtDNA sequences to amino acids in order to check for the possible presence of frameshifts or stop codons, which would indicate the presence of sequencing errors solución de $\mathrm{MgC}_{12} 15 \mathrm{mM}, 0.25 \mu \mathrm{L}$ de dNTP (10 mM de cada uno), $0.9 \mu \mathrm{L}$ de cada cebador $(10 \mu \mathrm{M}), 0.4 \mu \mathrm{L}$ de ADN polimerasa BIORON DFS-Taq $5 \mathrm{U} / \mu \mathrm{L}$ y $2 \mu \mathrm{L}$ de plantilla de ADN, para un volumen total de $25 \mu \mathrm{L}$. El ciclo térmico consistió en 35 ciclos de desnaturalización $\left(95^{\circ} \mathrm{C}\right.$ por $\left.50 \mathrm{~s}\right)$, alineamiento $\left(48^{\circ} \mathrm{C}\right.$ por $\left.50 \mathrm{~s}\right)$ y extensión $\left(72{ }^{\circ} \mathrm{C}\right.$ por $\left.50 \mathrm{~s}\right)$, seguido de 7 min a $72{ }^{\circ} \mathrm{C}$ para la etapa de extensión final. Después de la RCP, se separaron $5 \mu \mathrm{L}$ de cada producto de la RCP mediante electroforesis en un gel de agarosa al $2 \%$ a $90 \mathrm{~V}$ durante 20 min y se visualizaron con un transiluminador UV. Cuando los productos de RCP mostraron una banda clara y única de la longitud esperada, se purificaron utilizando el kit Exo-SAP-IT (Affymetrix USB) y se secuenciaron por Macrogen Inc. (Seúl, Corea del Sur) con un secuenciador ABI 3130xL (Applied Biosystems). Los mismos cebadores utilizados para la RCP se usaron posteriormente para la secuenciación directa del producto de la RCP, y la calidad de los cromatogramas obtenidos se verificó a través de la medición de sus puntuaciones de Phred (Richterich 1998). Solo se utilizaron secuencias con lecturas continuas de bases de alta calidad (QV > 20). Los cromatogramas se analizaron y revisaron manualmente con el software Chromas v.2.6.2 (Technelysium, Pty. Ltd. 1998; Queensland, Australia) y se alinearon con ClustalX v.2.1 (Larkin et al. 2007). 
or pseudogenes, a widespread phenomenon among crustaceans (e.g., Song et al. 2008, Schizas 2012), and to calculate the pairwise uncorrected ' $p$ ' distance based on the entire mtDNA dataset.

The molecular identification of the studied specimens and the reconstruction of the phylogenetic relationships among the taxa was performed with Bayesian inference (BI) and maximum likelihood (ML) methods as implemented in MrBayes v.3.2.6 (Ronquist et al. 2012) and PhyML v.3 (Guindon and Gascuel 2003), respectively. As a measure of branch support, bootstrap values (Felsenstein 1985) were calculated with 1,000 replicates in the ML tree, and posterior probability values were reported on the BI tree. The choice of the best evolutionary model was made using PartitionFinder v.1.0.1 (Lanfear et al. 2012) according to the Akaike information criterion (AIC, Akaike 1974). The BI and ML analyses were performed using a general time-reversible model of sequence evolution with a proportion of invariant sites $(\mathrm{GTR}+\mathrm{I}$; number substitution types $=6$ ). In the BI analyses, two independent Markov chain Monte Carlo analyses were run with 1 million generations (temp.: 0.2 ; default priors). Trees and parameter values were sampled every 100 generations, resulting in 10,000 saved trees per analysis; in the analysis, convergence was reached (effective sample size above 254.10); 2,500 trees were conservatively discarded as "burn-in".

A haplotype network including all the available T. fulvus COI sequences was constructed through the software PopART (v.1.7; http://popart.otago.ac.nz), using the minimum spanning method (Kruskal 1956) (Fig. S1).

In this study, the "evolutionary genetic species concept" proposed by Birky et al. (2010) was followed. According to this concept, species are inclusive populations that are evolving independently of each other, either because they are reproductively isolated, or because they are separated by environmental or physical barriers, or both. Those lineages that evolve separately from others were thus considered different taxa of putative species rank. In order to single out evolutionary lineages of species rank, DNA taxonomy approaches based on different assumptions were implemented, i.e., a quantitative approach based on coalescent model (ABGD, Puillandre et al. 2012), a phylogenetic criterion based on branching rates (bPTP, Zhang et al. 2013), and a genetic population criterion based on genetic isolation $(\mathrm{K} / \Theta$ ratio; Birky and Barraclough 2009, Birky et al. 2010, Birky 2013). Both ABGD and bPTP methods were implemented through their online interfaces (http://www.abi.snv.jussieu.fr/ public/abgd/abgdweb.html and http://species.h-its.org/ ptp/). Following Korn and Hundsdoerfer (2016), the K/ $\Theta$ ratio was computed based on the uncorrected $p$-distance matrices within and among the detected clades. This method tests if the reciprocal monophyly of sister lineages is statistically significant, which would suggest
Las 39 nuevas secuencias mitocondriales de T. fulvus y las 2 de T. brevicornis se depositaron en GenBank (ver la Tabla 1 para conocer sus números de acceso). Además, las únicas 2 secuencias de T. fulvus disponibles en GenBank se descargaron e incluyeron en los análisis (ver la Tabla 1 para conocer sus números de acceso).

Para traducir las secuencias de ADN mitocondrial a aminoácidos se usó el software MEGA v.7.0 (Kumar et al. 2016) para, así, poder evaluar la posible presencia de mutaciones con cambios del marco de lectura o codones de parada, lo que indicaría la presencia de errores de secuenciación o pseudogenes, un fenómeno generalizado en los crustáceos (e.g., Song et al. 2008, Schizas 2012), y para calcular la comparación por pares de la distancia ' $p$ ' no corregida en función del conjunto de datos del ADN mitocondrial.

La identificación molecular de los especímenes estudiados y la reconstrucción de las relaciones filogenéticas entre los taxones se realizaron con los métodos de inferencia bayesiana (IB) y de máxima verosimilitud (MV) implementados con el software MrBayes v.3.2.6 (Ronquist et al. 2012) y PhyML v.3 (Guindon y Gascuel 2003), respectivamente. Para medir el soporte de rama, los valores de bootstrap (Felsenstein 1985) se calcularon con 1,000 repeticiones en el árbol de MV y los valores de probabilidad posteriores se reportaron en el árbol IB. La elección del mejor modelo evolutivo se realizó utilizando PartitionFinder v.1.0.1 (Lanfear et al. 2012) de acuerdo con el criterio de información de Akaike (CIA, Akaike 1974). Los análisis de IB y MV se realizaron utilizando un modelo general de tiempo reversible de evolución de secuencia con una proporción de sitios invariantes $(\mathrm{GTR}+\mathrm{I}$; número de tipo de sustituciones $=6)$. En los análisis de IB, se ejecutaron 2 análisis independientes de cadenas de Markov de Monte Carlo con 1 millón de generaciones (temp: 0.2; estimador previo usado por defecto). Los árboles y los valores de los parámetros se muestrearon cada 100 generaciones, lo que dio como resultado 10,000 árboles guardados por análisis; en el análisis, se alcanzó la convergencia (tamaño de muestra efectivo por encima de 254.10); 2,500 árboles fueron descartados de forma conservadora como "burn-in".

Se construyó una red de haplotipos que incluyó todas las secuencias COI de T. fulvus disponibles usando el software PopART (v.1.7; http://popart.otago.ac.nz), utilizando el método del árbol de expansión mínima (Kruskal 1956) (Fig. S1).

En el marco de este estudio se siguió el concepto de "especie genética evolutiva" propuesto por Birky et al. (2010). Según este concepto, las especies son poblaciones inclusivas que están evolucionando independientemente unas de otras, ya sea porque están aisladas reproductivamente, o porque están separadas por barreras ambientales o físicas, o ambas cosas. Aquellos linajes que evolucionan por separado de otros se consideraron, por lo tanto, taxones diferentes con rango de especie putativa. Con el fin de señalar los linajes evolutivos del rango de especies, se implementaron enfoques 
that they are independently evolving entities, hence bonae species sensu Birky et al. (2010).

\section{RESULTS}

Overall, 41 Tigriopus specimens belonging to T. fulvus s.l. and T. brevicornis were analyzed, and included in the analyses (Table 1). According to the morphological study of the collected samples, the Algerian and Adriatic samples coming from the type localities of the alleged T. fulvus subspecies showed no consistent morphological differences when compared to the samples coming from Madeira Island, where the type locality of T. fulvus s.s. occurs, thus casting some doubts on the actual subspecific status of these populations. No specimens morphologically ascribable to the poorly characterized $T$. minutus were collected in this survey.

After having trimmed out the sequences, a properly aligned fragment $552 \mathrm{bp}$ long of the COI mtDNA gene was obtained. All the sequences were deposited in GenBank (accession numbers MK211324-MK211364).

The BI and ML trees based on the mitochondrial COI fragment and rooted on $T$. brevicornis showed a congruent topology, with a sister-taxa relationship between the Algerian samples from the T. fulvus algiricus type locality and the rest of the T. fulvus s.l. specimens, whereas the alleged T. f. adriaticus sample was nested well within the ingroup (Fig. 2). Well-supported Moroccan, Madeiran, and Mediterranean T. fulvus clades stemmed from a basal polytomy. The Mediterranean clade showed noteworthy internal molecular structuring, with intra-clade pairwise uncorrected $p$ distances ranging from $0 \%$ to $19 \%$. Interestingly, the occurrence of private monophyletic haplogroups was observed in different Mediterranean subbasins (see Figs. 1, 2), and no haplotypes were shared among different rock pools even within subbasins.

The initial and recursive partitions of the ABGD analysis found 16 groups of putative species rank within the ingroup, with prior maximal divergence of intraspecific diversity values $(p)$ ranging from 0.0129 to 0.0359 (Fig. S2). Among these 16 groups, two correspond to the Madeiran clade of $T$. fulvus s.s., as shown in the mtDNA based tree (Fig. 2). bPTP analysis estimated the presence of 21 putative species in the ingroup, i.e., finding 11 of the groups highlighted by ABGD analysis, and further splitting the other ones. Madeiran T. fulvus samples were ascribed to two different groups also by bPTP, as shown in Figure 2.

The $\mathrm{K} / \Theta$ ratio showed the presence of a single species in the ingroup, with inter-clade distances $(\mathrm{K})$ much lower than $4 \Theta$, i.e., 4 times the average sequence divergence among individuals of each clade (Table 2). The $\mathrm{K} / \Theta$ ratio thus does not support the existence of independently evolving lineages of species rank within the studied dataset. de taxonomía de ADN basados en diferentes supuestos, es decir, un enfoque cuantitativo basado en el modelo coalescente (ABGD, por sus siglas en inglés; Puillandre et al. 2012), un criterio filogenético basado en tasas de ramificación (bPTP, Zhang et al. 2013) y un criterio de población genética basado en el aislamiento genético (relación $\mathrm{K} / \Theta$; Birky y Barraclough 2009, Birky et al. 2010, Birky 2013). Los métodos ABGD y bPTP se implementaron a través de sus interfaces en línea (http://www.abi.snv.jussieu. fr/public/abgd/abgdweb.html y http://species.h-its.org/ptp/). Siguiendo a Korn y Hundsdoerfer (2016), se calculó la relación $\mathrm{K} / \Theta$ con base en las matrices de distancia $p$ no corregidas dentro y entre los clados detectados. Este método prueba si la monofilia recíproca de linajes hermanos es estadísticamente significativa, lo que sugeriría que son entidades que evolucionan independientemente, y por tanto bonae especies sensu Birky et al. (2010).

\section{Resultados}

En conjunto se recolectaron, analizaron e incluyeron en los análisis 41 especímenes de Tigriopus pertenecientes a T. fulvus s.l. y T. brevicornis (Tabla 1). De acuerdo con el estudio morfológico de las muestras recolectadas, las muestras argelinas y adriáticas provenientes de las localidades tipo de las supuestas subespecies de T. fulvus no mostraron diferencias morfológicas consistentes en la comparación con las muestras provenientes de la isla de Madeira, donde la localidad tipo de T. fulvus s.s. ocurre, lo que arroja algunas dudas sobre el status real de las diferentes subespecies de estas poblaciones. En este estudio no se recolectaron especímenes morfológicamente atribuibles a la especie T. minutus.

Después de haber recortado las secuencias, se obtuvo un fragmento correctamente alineado de $552 \mathrm{pb}$ de longitud del gen COI de ADN mitocondrial. Todas las secuencias se depositaron en GenBank (números de acceso MK211324-MK211364).

Los árboles IB y MV basados en el fragmento de COI mitocondrial y basados en T. brevicornis mostraron una topología congruente, con una relación de taxón hermano entre las muestras argelinas de la localidad tipo de T. fulvus algiricus y el resto de especímenes de T. fulvus s.l, mientras que la supuesta muestra de T. f. adriaticus se enclavo bien dentro de su grupo (Fig. 2). Los clados de Marruecos, Madeira y del Mediterraneo de T. fulvus parten de una politomía basal bien fundamentada. El clado mediterráneo mostró una estructura molecular interna notable, con distancias $p$ no corregidas por pares intra-clado que oscilaron entre $0 \%$ y $19 \%$. Resulta interesante la aparición de haplogrupos monofiléticos privados observada en diferentes subcuencas del Mediterráneo (ver Figs. 1,2); no se compartieron haplotipos entre diferentes charcas a nivel de subcuenca.

Las particiones iniciales y recursivas del análisis ABGD encontraron 16 grupos de especies putativas dentro del grupo, con divergencia máxima previa de valores de diversidad 


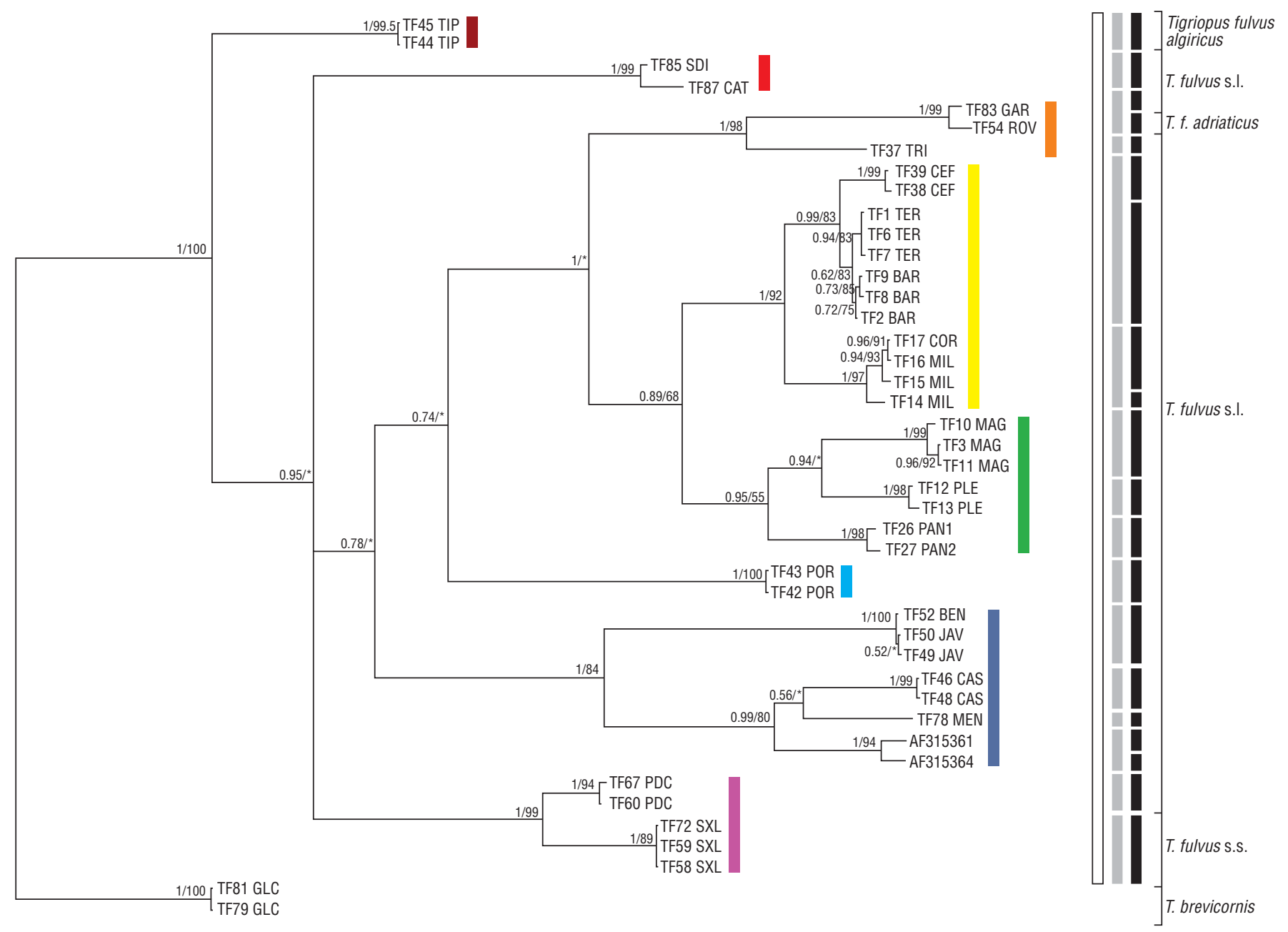

Figure 2. Bayesian phylogram (95\% majority rule consensus tree) for Tigriopus spp. based on the 552 bp fragment of the mtDNA COI. Samples of Tigriopus brevicornis were used as outgroup to root the tree. Node statistical support is reported as nodal posterior probabilities (Bayesian Inference of phylogeny, BI)/bootstrap values (Maximum Likelihood, ML). Asterisks indicate a bootstrap support value lower than 50. Rectangles refer to MOTUs as indicated by the $\mathrm{K} / \Theta$ ratio (white rectangle), ABGD (gray rectangles), and bPTP (black rectangles). Square brackets group the samples according to the current taxonomy of the genus. The analyzed specimens are reported using the codes listed in Table 1.

Figura 2. Filograma bayesiano (árbol de consenso de la regla de mayoría al 95\%) de Tigriopus spp. basado en el fragmento de 552 pb del ADNmt COI. Se utilizaron muestras de Tigiropus brevicornis como grupo externo. El soporte estadístico de los nodos se informa como probabilidades nodales posteriores (inferencia bayesiana de la filogenia, BI)/valores bootstrap (verosimilitud máxima, ML). Los asteriscos indican un valor de soporte de bootstrap inferior a 50. Los rectángulos se refieren a los MOTU indicados por la relación K/ $\Theta$ (rectángulo blanco), ABGD (rectángulos grises) y bPTP (rectángulos negros). Los corchetes agrupan las muestras según la taxonomía actual del género. Los especímenes analizados se indican utilizando los códigos que se enumeran en la Tabla 1.

\section{Discussion}

\section{Taxonomical notes}

The ABGD and bPTP DNA taxonomy approaches used in the frame of this work suggested the presence of an unexpectedly high number of species within the ingroup. Conversely, according to the same dataset, the $\mathrm{K} / \Theta$ ratio identified the presence of a single species in the whole study area, namely T. fulvus. However, sample size is known to differently affect the accuracy of the molecular taxonomy approaches implemented in our analyses as ABGD and bPTP are more sensitive intraespecífica $(p)$ de 0.0129 a 0.0359 (Fig. S2). Entre estos 16 grupos, dos corresponden al clado de Madeira de T. fulvus s.s., como se muestra en el árbol basado en ADN mitocondrial (Fig. 2). El análisis de bPTP estimó la presencia de 21 especies putativas dentro del grupo, es decir, encontrando 11 de los grupos destacados por el análisis ABGD, y dividiendo los otros. Las muestras de T. fulvus de Madeira se asignaron a 2 grupos diferentes también por bPTP, como se muestra en la Figura 2.

La relación $\mathrm{K} / \Theta$ mostró la presencia de una sola especie dentro del grupo, con distancias entre clados $(\mathrm{K})$ mucho más bajas que $4 \Theta$, es decir, 4 veces la divergencia de secuencia 
to the size of the sample (Pulliandre et al. 2012, Zhang et al. 2013), whereas the $K / \Theta$ ratio should be not significantly influenced by the sample size (cf. Birky 2013). Moreover, it should be kept in mind that DNA taxonomy approaches just delimit primary species hypotheses, i.e., indications that, taken alone, are not sufficient to clarify the taxonomical rank to be attributed to the studied clades. It is thus necessary to adopt an integrative approach and search for a consensus between their outputs before delineating species (Fontaneto et al. 2015). For these reasons, lacking a consensus among the outputs of the different DNA taxonomy approaches implemented and pending a wider sampling coverage of Tigriopus molecular diversity in the whole Atlantic-Mediterranean area, we opted to rely on the results of the $\mathrm{K} / \Theta$ ratio approach, which is considered the most conservative method among the implemented molecular taxonomy approaches (Birky and Barraclough 2009, Bode et al. 2010). Moreover, the morphological study of the samples highlighted that the morphological features used to distinguish the subspecies fall, in fact, within the internal variability of the species (L Vecchioni in prep.); this, coupled with the branching pattern of the phylogenetic tree (Fig. 2), suggests that the currently described T. fulvus subspecies are to be considered as junior synonyms of $T$. fulvus s.s., although a wider sampling of the overall morphological and molecular diversity of Atlantic-Mediterranean Tigriopus populations is desirable. Currently available morphological and molecular data therefore suggest that only T. fulvus occurs in the study area, but more surveys aimed at obtaining a clearer picture of its overall diversity are needed. promedio entre los individuos de cada clado (Tabla 2). Por lo tanto, la relación $\mathrm{K} / \Theta$ no admite la existencia de linajes que evolucionan a rango de especie de manera independiente dentro del rango de datos estudiado.

\section{Discusión}

\section{Notas taxonómicas}

Los enfoques de taxonomía de ADN ABGD y bPTP utilizados en este trabajo sugirieron la presencia de un número inesperadamente alto de especies dentro del grupo. Por el contrario, basándose en el mismo conjunto de datos, la relación $\mathrm{K} / \Theta$ identificó la presencia de una sola especie en toda el área de estudio, T. fulvus. Sin embargo, se sabe que el tamaño de la muestra afecta de manera diferente la precisión de los enfoques de taxonomía molecular implementados en nuestros análisis, ya que ABGD y bPTP son más sensibles al tamaño de la muestra (Pulliandre et al. 2012, Zhang et al. 2013), mientras que la relación $\mathrm{K} / \Theta$ no debe verse afectada significativamente por el tamaño de la muestra (cf. Birky 2013). Además, debe tenerse en cuenta que la taxonomía basada en ADN solo delimita las hipótesis de las especies primarias, es decir, indicaciones que, tomadas por sí solas, no son suficientes para aclarar el rango taxonómico que se debe atribuir a los clados estudiados. Por lo tanto, es necesario adoptar un enfoque integrador y buscar un consenso entre sus resultados antes de delimitar las especies (Fontaneto et al. 2015). Por estas razones, al carecer de un consenso

Table 2. Application of the $\mathrm{K} / \Theta$ ratio to Tigriopus fulvus s.l. mitochondrial lineages. $n$ : number of individuals; $p$-dist.: uncorrected $p$ distance; $\pi$ : nucleotide diversity; $\Theta$ : intra-clade variation; $\mathrm{K}$ : inter-clade distance; Tfulvcm: T. fulvus from the central Mediterranean area; Tfadr: T. f. adriaticus; Tfalg: T. f. algiricus; Tfulvss: T. fulvus s.s. from Madeira; Tfulvsl: T. fulvus s.l.

Tabla 2. Aplicación de la relación $\mathrm{K} / \Theta$ a los linajes mitocondriales de Tigriopus fulvus s.l.. $n$ : número de individuos; $p$-dist: distancia $p$ no corregida; $\pi$ : diversidad de nucleótidos; $\Theta$ : variación intraclado; K: distancias interclados; Tfulvcm: T. fulvus del área central del Mediterráneo; Tfadr: T. f. adriaticus; Tfalg: T. f. algiricus; Tfulvss: T. fulvus s.s. de Madeira; Tfulvsl: T. fulvus s.l.

\begin{tabular}{|c|c|c|c|c|c|c|c|c|}
\hline Tfulvem & 19 & 0.112 & 0.118 & 0.157 & 0.140 & 0.188 & 0.868 & $\begin{array}{l}\text { TF1, TF2, TF3, TF6, TF7, TF8, TF9, TF10, } \\
\text { TF11, TF12, TF13, TF14, TF15, TF16, TF17, } \\
\text { TF26, TF27, TF38, TF39 }\end{array}$ \\
\hline Tfadr & 3 & 0.112 & 0.168 & 0.224 & 0.216 & 0.188 & 0.868 & TF37, TF54, TF83 \\
\hline Tfulvsp1 & 22 & 0.062 & 0.064 & 0.086 & 0.071 & 0.212 & 2.981 & Tfulvem + Tfadr \\
\hline Tfulvsp3 & 24 & 0.143 & 0.149 & 0.198 & 0.186 & 0.228 & 1.053 & Tfulvsp1 + Tfulvsp2 \\
\hline Tfulvsp4 & 6 & 0.140 & 0.168 & 0.224 & 0.216 & 0.228 & 1.053 & TF46, TF48, TF49, TF50, TF52, TF78 \\
\hline Tfulvsp5 & 30 & 0.033 & 0.034 & 0.045 & 0.035 & 0.225 & 0.357 & Tfulvsp3 + Tfulvsp4 \\
\hline Tfulvsp6 & 2 & 0.171 & 0.342 & 0.456 & 0.628 & 0.220 & 2.545 & TF85, TF87 \\
\hline
\end{tabular}




\section{Pattern of molecular diversity}

The phylogenetic analysis of the studied AtlanticMediterranean T. fulvus populations revealed noteworthy geographic structuring of the genetic diversity among the samples (Figs. 1, 2), with inter-population mitochondrial divergence values reaching up to $19 \%$. This is in accordance with the known occurrence of high genetic diversity in the North Atlantic T. brevicornis (0-21\%, Handschumacher et al. 2010), the Pacific Japanese T. japonicus Mori 1938 (0-23\%, Ki et al. 2009), and the Pacific North American T. californicus (Baker 1912) (0-23\%, Edmands 2001). According to Handschumacher et al. (2010), the extensive inter-population divergence observed in $T$. brevicornis could be ascribed to the "paradox of Rockall". This paradox states that species with limited dispersal and scarce inter-population gene flow are very effective in colonizing remote areas after fortuitous long-range passive dispersal events (Johannesson 1988), thus resulting in the establishment of isolated but widespread populations.

Southern populations of T. californicus and T. brevicornis have been found to be genetically distinct from each other, while the northernmost populations appear to show substantially lower inter-population divergences (Edmands 2001, Handschumacher et al. 2010). This pattern is in accordance with the "Southern richness vs. Northern purity" paradigm (Hewitt 2004, Marrone et al. 2010), where the "northern purity" is attributed to the post-glacial recolonization of the northern area by a subset of the diversity survived in peripheral or southern refugia during glacial events, and the "southern richness" to the continuous persistence of the populations in these areas.

A similar pattern was observed in other species inhabiting rock pools (e.g., in the dipteran genus Aedes, Mastrantonio et al. 2015), whereas the high genetic structure in rock-pool dwelling coleopterans of the genus Calobius was considered in good accordance with the theory of the "refugia within refugia" (Gómez and Lunt 2006, Antonini et al. 2010). However, the role that recent bottlenecks and/or founder effects might have on the genetic structuring of rock-pool dwelling organisms should also be considered (cf. Audisio et al. 2010).

The high level of geographically based genetic structure observed in the Atlantic-Mediterranean Tigriopus populations seems in good accordance with the non-cosmopolitanism paradigm of aquatic taxa and the monopolization hypothesis (De Meester et al. 2002, Incagnone et al. 2015). This hypothesis predicts that the monopolization of water bodies by the first colonizers leads to a long-lasting persistent founder effect; this generates a structured pattern of genetic diversity that mirrors the history of colonization rather than deterministic environmental factors (e.g., Ventura et al. 2014, but see also Kappas et al. 2017). However, the present case study slightly differs from this pattern since Tigriopus populations are known to be frequently wiped out by physical events entre los resultados de los diferentes enfoques de taxonomía basada en ADN implementados y en espera de una cobertura de muestreo más amplia de la diversidad molecular de Tigriopus en toda el área atlántico-mediterránea, optamos por confiar en los resultados del enfoque de la relación $\mathrm{K} / \Theta$, que se considera el método más conservador entre los enfoques de taxonomía molecular implementados (Birky y Barraclough 2009, Bode et al. 2010). Además, el estudio morfológico de las muestras destacó que las características morfológicas utilizadas para distinguir las subespecies se encuentran, de hecho, dentro de la variabilidad interna de la especie (L Vecchioni en preparación); esto, junto con el patrón de ramificación del árbol filogenético (Fig. 2), sugiere que las subespecies de T. fulvus descritas actualmente se consideran como un sinónimo menor de T. fulvus s.s., aunque un muestreo más amplio de la morfología general y de la diversidad molecular de las poblaciones de Tigriopus atlántico-mediterráneas es deseable. Los datos morfológicos y moleculares disponibles actualmente sugieren que solo se encuentra una especie, T. fulvus, en el área de estudio, aunque se necesitan más muestreos para obtener una imagen más clara de su diversidad general.

\section{Patrón de diversidad molecular}

El análisis filogenético de las poblaciones atlánticomediterráneas de $T$. fulvus estudiadas reveló una estructuración geográfica notable de la diversidad genética entre las muestras (Figs. 1, 2), con valores de divergencia mitocondrial interpoblacional que alcanzaron hasta el 19\%. Esto concuerda con la conocida presencia de una alta diversidad genética en la especie del Atlántico Norte T. brevicornis (0-21\%, Handschumacher et al. 2010), en la especie japonesa del Pacífico Tigriopus japonicus Mori 1938 (0-23\%, $\mathrm{Ki}$ et al. 2009), y en la especie norteamericana del Pacífico T. californicus (Baker 1912) (0-23\%, Edmands 2001). Según Handschumacher et al. (2010), la gran diversidad interpoblacional observada en $T$. brevicornis podría atribuirse a la "paradoja de Rockall". La paradoja indica que las especies con una capacidad de dispersión limitada y escaso flujo genético entre poblaciones son muy efectivas en la colonización de áreas remotas después de eventos fortuitos de dispersión pasiva de largo alcance (Johannesson 1988), lo que resulta en el establecimiento de poblaciones aisladas, pero con una distribución extensa.

Se ha encontrado que las poblaciones del sur de T. californicus y T. brevicornis son genéticamente distintas unas de otras, mientras que las poblaciones más al norte parecen presentar divergencias interpoblaciónales sustancialmente más bajas (Edmands 2001, Handschumacher et al. 2010). Este patrón concuerda con el paradigma de "riqueza del sur frente a la pureza del norte" (Hewitt 2004, Marrone et al. 2010), donde la "pureza del norte" se atribuye a la recolonización postglacial de la zona norte por un subconjunto de la diversidad que sobrevivió en refugios periféricos 
(e.g., exceptional droughts, storms, or rainfalls), leading to recurrent local extinctions and recolonizations. Accordingly, those Tigriopus haplotypes that colonize a Tigriopus-free rock pool rapidly monopolize it preventing the establishment of other haplotypes, but this monopolization only lasts a relatively short amount of time, i.e., until a new event wipes this population out. Thus, unlike in the monopolization hypothesis, a long-lasting founder effect is not achieved, but rather just a temporary occurrence of monopolizing haplotypes can be observed. Such a pattern could be defined as a "clockwork monopolization", related to the great instability of the rock pool habitats and to the inability of their inhabitants to produce long-lasting resting stages.

\section{ACKNOWLEDGMENTS}

We wish to thank Prof. Vezio Cottarelli for the help he provided us with the collection of some samples of $T$. fulvus and for the stimulating discussions we had on the topic of this manuscript. G Alfonso (University of Salento, Italy) and A Millán (University of Murcia, Spain) kindly provided some of the studied samples.

\section{REFERENCES}

Akaike H. 1974. A New look at the statistical model identification. IEEE Trans. Automat. Contr. 19(6): 716-723. https://doi.org/10.1109/TAC.1974.1100705

Antonini G, Audisio P, Mancini E, De Biase A, Tronci C, Rossetti G, Trizzino M. 2010. Molecular phylogeography of two Italian sibling species of Calobius (Coleoptera, Hydraenidae, Ochthebiinae) inhabiting mediterranean marine rock-pools. Mar. Biol. 157(2): 371-381.

https://doi.org/10.1007/s00227-009-1324-9

Audisio P, Trizzino M, De Biase A, Rossetti G, Mancini E, Antonini G. 2010. Molecular and morphological evidence of a new sibling species of Calobius (Coleoptera: Hydraenidae) of the $C$. quadricollis complex from peninsular Italy. Ital. J. Zool. 77(1): 29-37. https://doi.org/10.1080/11250000902845738

Battaglia B. 1982. Genetic variation and speciation events in marine copepods. In: Liss AR (ed.), Mechanisms of Speciation. New York: A.R. Liss Inc.; pp. 377-392.

Birky CW, Adams J, Gemmel M, Perry J. 2010. Using population genetic theory and DNA sequences for species detection and identification in asexual organisms. PLoS ONE 5(5). e1069. https://doi.org/10.1371/journal.pone.0010609

Birky CW Jr, Barraclough TG. 2009. Asexual Speciation. In: Schön I, Martens K, Dijk P (eds.), Lost Sex. Dordrecht (Netherlands): Springer. https://doi.org/10.1007/978-90-481-2770-2_10

Birky CW Jr. 2013. Species detection and identification in sexual organisms using population genetic theory and DNA Sequences. PLoS ONE 8. e52544. https://doi.org/10.1371/journal.pone.0052544

Bode SNS, Adolfsson S, Lamatsch DK, Martins MJF, Schmit O, Vandekerkhove J, Mezquita F, Namiotko T, Rossetti G, Schön I et al. 2010. Exceptional cryptic diversity and multiple origins of parthenogenesis in a freshwater ostracod. Mol. Phyl. Evol. 54(2): 542-552.

https://doi.org/10.1016/j.ympev.2009.08.022 o del sur durante los periodos glaciares, y la "riqueza del sur" a la persistencia continua de las poblaciones en estas áreas.

Un patrón similar se ha encontrado en otras especies que habitan en las charcas de roca (e.g., en el género díptero Aedes, Mastrantonio et al. 2015), en tanto que la alta estructuración genética de los coleópteros del género Calobius que hábitan en estas charcas de rocas fue considerada por Antonini et al. (2010) en concordancia con la teoría de los "refugios dentro de los refugios" (Gómez y Lunt 2006, Antonini et al. 2010). No obstante, también debe considerarse el papel que los cuellos de botella recientes y/o el efecto fundador podrían tener en la estructuración genética de los organismos que habitan en las charcas de las rocas (cf. Audisio et al. 2010).

El alto nivel de estructuración genética a nivel geográfico observada en las poblaciones atlántico-mediterráneas de Tigriopus parece concordar con el paradigma de no cosmopolitismo de los taxones acuáticos y la hipótesis de monopolización (De Meester et al. 2002, Incagnone et al. 2015). La hipótesis mencionada predice que la monopolización de los cuerpos de agua por parte de los colonizadores primarios conduce a un efecto fundador persistente y duradero; esto genera un patrón estructurado de diversidad genética que refleja la historia de la colonización en lugar de factores ambientales deterministas (e.g., Ventura et al. 2014, pero vea también Kappas et al. 2017). Sin embargo, los resultados del presente estudio difieren ligeramente de este patrón, ya que se sabe que las poblaciones de Tigriopus desaparecen con frecuencia por eventos físicos (e.g., sequías excepcionales, tormentas o lluvias) que conducen a extinciones locales y recolonizaciones recurrentes. En consecuencia, los haplotipos de Tigriopus que colonizan una charcas de rocas libre de Tigriopus la monopolizan rápidamente impidiendo el establecimiento de otros haplotipos, pero esta monopolización solo dura un tiempo relativamente corto, es decir, hasta que un nuevo evento borre a esta población. Por lo tanto, a diferencia de la hipótesis de monopolización, no se logra un efecto fundador de larga duración, sino que solo se puede observar una ocurrencia temporal de haplotipos monopolizantes. Tal patrón podría definirse como una "monopolización periódica" ("clockwork monopolization", relacionada con la gran inestabilidad de los hábitats de las charcas de roca y la incapacidad de sus habitantes para producir etapas de resistencia de larga duración.

\section{Agradecimientos}

Agradecemos al profesor Vezio Cottarelli la ayuda que nos brindó con la recopilación de algunas muestras de T. fulvus y por las estimulantes discusiones que tuvimos sobre el tema de este manuscrito. G Alfonso (Universidad de Salento, Italia) y A Millán (Universidad de Murcia, España) proporcionaron amablemente algunas de las muestras estudiadas. 
Carli A, Fiori A. 1977. Morphological analysis of the two Tigriopus species found along the European coasts. Soc. Ital. Sci. Nat. Mus. Civ. Stor. Nat. e Acquar. Civ. Milano. 68: 101-110.

De Meester L, Gómez A, Okamura B, Schwenk K. 2002. The monopolization hypothesis and the dispersal-gene flow paradox in aquatic organisms. Acta Oecologica. 23(3): 121-135. https://doi.org/10.1016/S1146-609X(02)01145-1

Dethier MN. 1980. Tidepools as refuges: Predation and the limits of the harpacticoid copepod Tigriopus californicus (Baker). J. Exp. Mar. Bio. Ecol. 42(2): 99-111. https://doi.org/10.1016/0022-0981(80)90169-0

Edmands S. 2001. Phylogeography of the intertidal copepod Tigriopus californicus reveals substantially reduced population differentiation at northern latitudes. Mol. Ecol. 10(7): 17431750 . https://doi.org/10.1046/j.0962-1083.2001.01306.x

Felsenstein J. 1985. Confidence limits on phylogenies: An approach using the bootstrap. Evolution. 39(4): 783-791. https://doi.org/10.2307/2408678

Fontaneto D, Flot JF, Tang CQ. 2015. Guidelines for DNA taxonomy, with a focus on the meiofauna. Mar. Biodivers. 45(3): 433-451. https://doi.org/10.1007/s12526-015-0319-7

Ganning B, WulffF. 1970. Measurements of community metabolism in some baltic brackish water rockpools by means of diel oxygen curves. Oikos, Nord Soc. 21(2): 292-298. https://doi.org/10.2307/3543686

Ganz HH, Burton RS. 1995. Genetic differentiation and reproductive incompatibility among Baja California populations of the copepod Tigriopus californicus. Mar. Biol. 123(4): 821-827. https://doi.org/10.1007/BF00349126

Gómez A, Lunt DH. 2006. Refugia within refugia: patterns of phylogeographic concordance in the Iberian Peninsula. In: Weiss S, Ferrand N (eds.), Phylogeography of Southern European Refugia. Netherlands: Springer, pp. 155-188. https://doi.org/10.1007/1-4020-4904-8_5

Guindon S, Gascuel O. 2003. A simple, fast, and accurate algorithm to estimate large phylogenies by maximum likelihood. Syst. Biol. 52(5): 696-704. https://doi.org/10.1080/10635150390235520

Handschumacher L, Steinarsdóttir MB, Edmands S, Ingólfsson A. 2010. Phylogeography of the rock-pool copepod Tigriopus brevicornis (Harpacticoida) in the northern North Atlantic, and its relationship to other species of the genus. Mar. Biol. 157(6): 1357-1366. https://doi.org/10.1007/s00227-010-1415-7

Hewitt GM. 2004. Genetic consequences of climatic oscillations in the Quaternary. Philos. Trans. R. Soc. Lond. B. Biol. Sci. 359(1442): 183-95. https://oi.org/10.1098/rstb.2003.1388

Incagnone G, Marrone F, Barone R, Robba L, Naselli-Flores L. 2015. How do freshwater organisms cross the "dry ocean"? A review on passive dispersal and colonization processes with a special focus on temporary ponds. Hydrobiologia 750(1): 103-123. https://doi.org/10.1007/s10750-014-2110-3

[ICZN] International Commission on Zoological Nomenclature. 1999. International Code of Zoological Nomenclature. 4th edition). London (United Kingdom): International Trust for Zoological Nomenclature; $306 \mathrm{pp}$.

Johannesson K. 1988. The paradox of Rockall: why is a brooding gastropod (Littorina saxatilis) more widespread than one having a planktonic larval dispersal stage (L. littorea)? Mar. Biol. 99(4): 507-513. https://doi.org/10.1007/BF00392558

Jung SO, Lee YM, Park TJ, Park HG, Hagiwara A, Leung KMY, Dahms HU, Lee W, Lee JS. 2006. The complete mitochondrial genome of the intertidal copepod Tigriopus sp. (Copepoda,
Harpactidae) from Korea and phylogenetic considerations. J. Exp. Mar. Bio. Ecol. 333(2): 251-262. https://doi.org/10.1016/j.jembe.2005.12.047

Kappas I, Mura G, Synefiaridou D, Marrone F, Alfonso G, Alonso M, Abatzopoulos TJ. 2017. Molecular and morphological data suggest weak phylogeographic structure in the fairy shrimp Streptocephalus torvicornis (Branchiopoda, Anostraca). Hydrobiologia 801(1): 21-32.

https://doi.org/10.1007/s10750-017-3203-6

Ki JS, Lee KW, Park HG, Chullasorn S, Dahms HU, Lee JS. 2009. Phylogeography of the copepod Tigriopus japonicus along the Northwest Pacific rim. J. Plankton. Res. 31(2): 209-221. https://doi.org/10.1093/plankt/fbn100

Korn M, Hundsdoerfer AK. 2016. Molecular phylogeny, morphology and taxonomy of Moroccan Triops granarius (Lucas, 1864) (Crustacea: Notostraca), with the description of two new species. Zootaxa 4178(3): 328-346. https://doi.org/10.11646/zootaxa.4178.3.2

Kruskal JB. 1956. On the shortest spanning subtree of the graph and the travelling salesman problem. Proc. Amer. Math. Soc. 7(1): 48-50. https://doi.org/10.1090/S0002-9939-1956-0078686-7

Kumar S, Stecher G, Tamura K. 2016. MEGA7: Molecular evolutionary genetics analysis version 7.0 for bigger datasets. Mol. Biol. Evol. 33(7): 1870-1874. https://doi.org/10.1093/molbev/msw054

Lanfear R, Calcott B, Ho SYW, Guidon S. 2012. PartitionFinder: Combined selection of partitioning schemes and substitution models for phylogenetic analyses. Mol. Biol. Evol. 29(6): 1695-1701. https://doi.org/10.1093/molbev/mss020

Lang K. 1948. Monographe der Harpacticiden I, II. [Reprint]. Konigsten (Germany): Otto Koeltz Science Publ; p. 1682.

Larkin MA, Blackshields G, Brown NP, Chenna R, McGettigan PA, McWilliam H, Valentin F, Wallace IM, Wilm A, Lopez R et al. 2007. Clustal $\mathrm{W}$ and Clustal $\mathrm{X}$ version 2.0. Bioinformatics 23(21): 2947-2948. https://doi.org/10.1093/bioinformatics/btm404

Lazzaretto I, Libertini A. 1986. Karyological comparison among different Mediterranean populations of the genus Tigriopus (Copepoda Harpacticoida). Bolletino di Zool. 53(2): 197-201. https://doi.org/10.1080/11250008609355503

Machida RJ, Miya MU, Nishida M, Nishida S. 2004. Large-scale gene rearrangements in the mitochondrial genomes of two calanoid copepods Eucalanus bungii and Neocalanus cristatus (Crustacea), with notes on new versatile primers for the srRNA and COI genes. Gene. 332: 71-78. https://doi.org/10.1016/j.gene.2004.01.019

Marrone F, Brutto SL, Arculeo M. 2010. Molecular evidence for the presence of cryptic evolutionary lineages in the freshwater copepod genus Hemidiaptomus G.O. Sars, 1903 (Calanoida, Diaptomidae). Hydrobiologia 644(1): 115-125. https://doi.org/10.1007/s10750-010-0101-6

Mastrantonio V, Porretta D, Bellini R, Nascetti G, Urbanelli S. 2015. Molecular systematics and origin of the Mediterranean Sea rock-pool mosquitoes of the Aedes mariae (Diptera: Culicidae) Complex. Ann. Entomol. Soc. Am. 108(4): 593-599. https://doi.org/10.1093/aesa/sav031

McAllen R. 1999. Enteromorpha intestinalis-A refuge for the supralittoral rock-pool harpacticoid copepod Tigriopus brevicornis. J. Mar. Biol. Assoc. United Kingdom. 79(6): $1125-1126$. https://doi.org/10.1017/S0025315499001393

Monard A. 1935. Note préliminaire sur la faune des Harpacticoides marins d'Alger. Bull. des Trav la Stn d'aquiculture pêche Castiglione 1-85. 
Park EO, Lee S, Cho M, Yoon SH, Lee Y, Lee W. 2014. A new species of the genus Tigriopus (Copepoda: Harpacticoida: Harpacticidae) from Antarctica. Proc. Biol. Soc. Washingt. 127(1): 138-154. https://doi.org/10.2988/0006-324X-127.1.138

Powlik JJ. 1998. Seasonal abundance and population flux of Tigriopus californicus (Copepoda: Harpacticoida) in Barkley Sound, British Columbia. J. Mar. Biol. Assoc. United Kingdom. 78(2): 467-481. https://doi.org/10.1017/S0025315400041564

Puillandre N, Lambert A, Brouillet S, Achaz G. 2012. ABGD, Automatic barcode gap discovery for primary species delimitation. Mol. Ecol. 21(8): 1864-1877. https://doi.org/10.1111/j.1365-294X.2011.05239.x

Raisuddin S, Kwok KWH, Leung KMY, Schlenk D, Lee JS. 2007. The copepod Tigriopus: A promising marine model organism for ecotoxicology and environmental genomics. Aquat. Toxicol. 83(3): 161-173. https://doi.org/10.1016/j.aquatox.2007.04.005

Richterich P. 1998. Estimation of errors in "raw" DNA sequences: A validation study error rate prediction accuracy for six projects. Genome Res. 8(1): 251-259. https://doi.org/10.1101/gr.8.3.251

Ronquist F, Teslenko M, Van Der Mark P, Ayres DL, Darling A, Höhna S, Larget B, Liu L, Suchard MA, Huelsenbeck JP. 2012. MrBayes 3.2: Efficient Bayesian phylogenetic inference and model choice across a large model space. Syst. Biol. 61(3): 539-542. https://doi.org/10.1093/sysbio/sys029

Schizas NV. 2012. Misconceptions regarding nuclear mitochondrial pseudogenes (Numts) may obscure detection of mitochondrial evolutionary novelties. Aquat. Biol. 17(1): 91-96. https://doi.org/10.3354/ab00478

Song H, Buhay JE, Whiting MF, Crandall KA. 2008. Many species in one: DNA barcoding overestimates the number of species when nuclear mitochondrial pseudogenes are coamplified. Proc. Natl. Acad. Sci. 105(36): 13486-13491. https://doi.org/10.1073/pnas.0803076105

Underwood AJ, Skilleter GA. 1996. Effects of patch-size on the structure of assemblages in rock pools. J. Exp. Mar. Bio. Ecol. 197(1): 63-90. https://doi.org/10.1016/0022-0981(95)00145-X

Van Douwe C. 1913. Tigriopus fulvus Fisher, var. adriatica, ein typischer Rock pools-Copepode. Biol. Zentralblatt. 33: 256-258.

Ventura M, Petrusek A, Miró A, Hamrová E, Buñay D, De Meester L, Mergeay J. 2014. Local and regional founder effects in lake zooplankton persist after thousands of years despite high dispersal potential. Mol. Ecol. 23(5): 1014-1027. https://doi.org/10.1111/mec.12656

Waller CL, Worland MR, Convey P, Barnes DKA. 2006. Ecophysiological strategies of Antarctic intertidal invertebrates faced with freezing stress. Polar. Biol. 29(12): 1077-1083. https://doi.org/10.1007/s00300-006-0152-3

Walter TC, Boxshall G. 2018. World of Copepods database. Tigriopus fulvus (Fischer, 1860). [Place of publication unknown]: World Register of Marine Species; [2018 Nov 15] http://www.marinespecies.org/aphia.php? $p=$ taxdetails\&id=116184.

Wells JBJ. 2007. An annotated checklist and keys to the species of Copepoda Harpacticoida (Crustacea). Auckland (New Zealand): Magnolia Press. (Zootaxa; vol. 1568); ISBN 978-1-86977-110-2.

Williams DD. 2007. The Biology of Temporary Waters. London: Oxford University Press; ISBN: 9780198528128.

Zhang J, Kapli P, Pavlidis P, Stamatakis A. 2013. A general species delimitation method with applications to phylogenetic placements. Bioinformatics 29(22): 2869-2876. https://doi.org/10.1093/bioinformatics/btt499

Received January 2019, accepted June 2019. 


\section{Supplementary material}

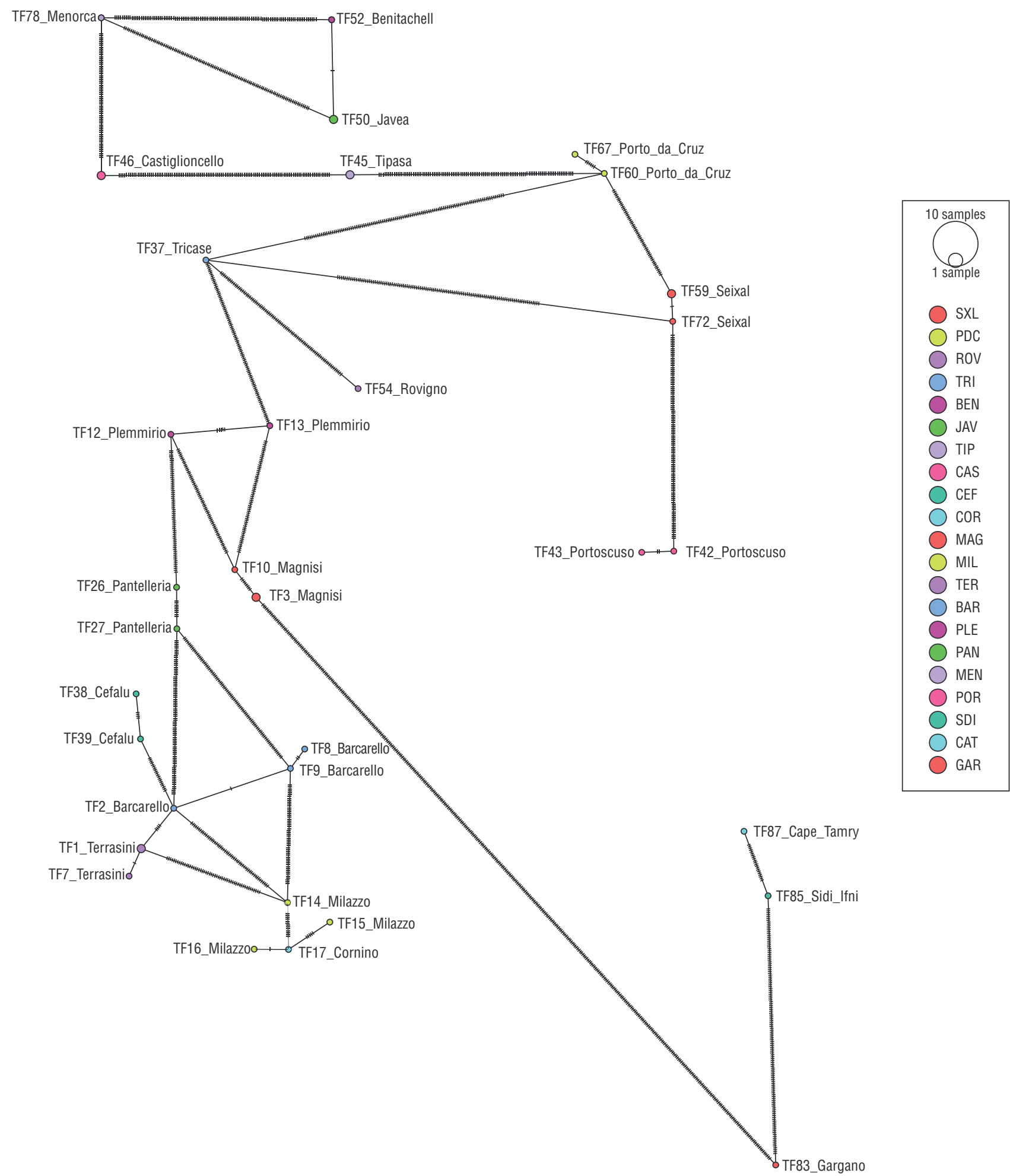

Figure S1. Minimum-spanning haplotype network based on a 552-bp long fragment of the mtDNA COI of Tigriopus fulvus. Dashes indicate substitution steps. Each circle represents a haplotype and its size is proportional to its frequency. The analyzed specimens are reported using the codes listed in Table 1.

Figura S1. Red de haplotipos de expansión mínima basada en un fragmento de 552 pb de largo del ADN mitocondrial del gen COI de Tigriopus fulvus. Los guiones indican sustituciones. Cada círculo representa un haplotipo y su tamaño es proporcional a su frecuencia. Los especímenes analizados se identifican con los códigos que se enumeran en la Tabla 1. 

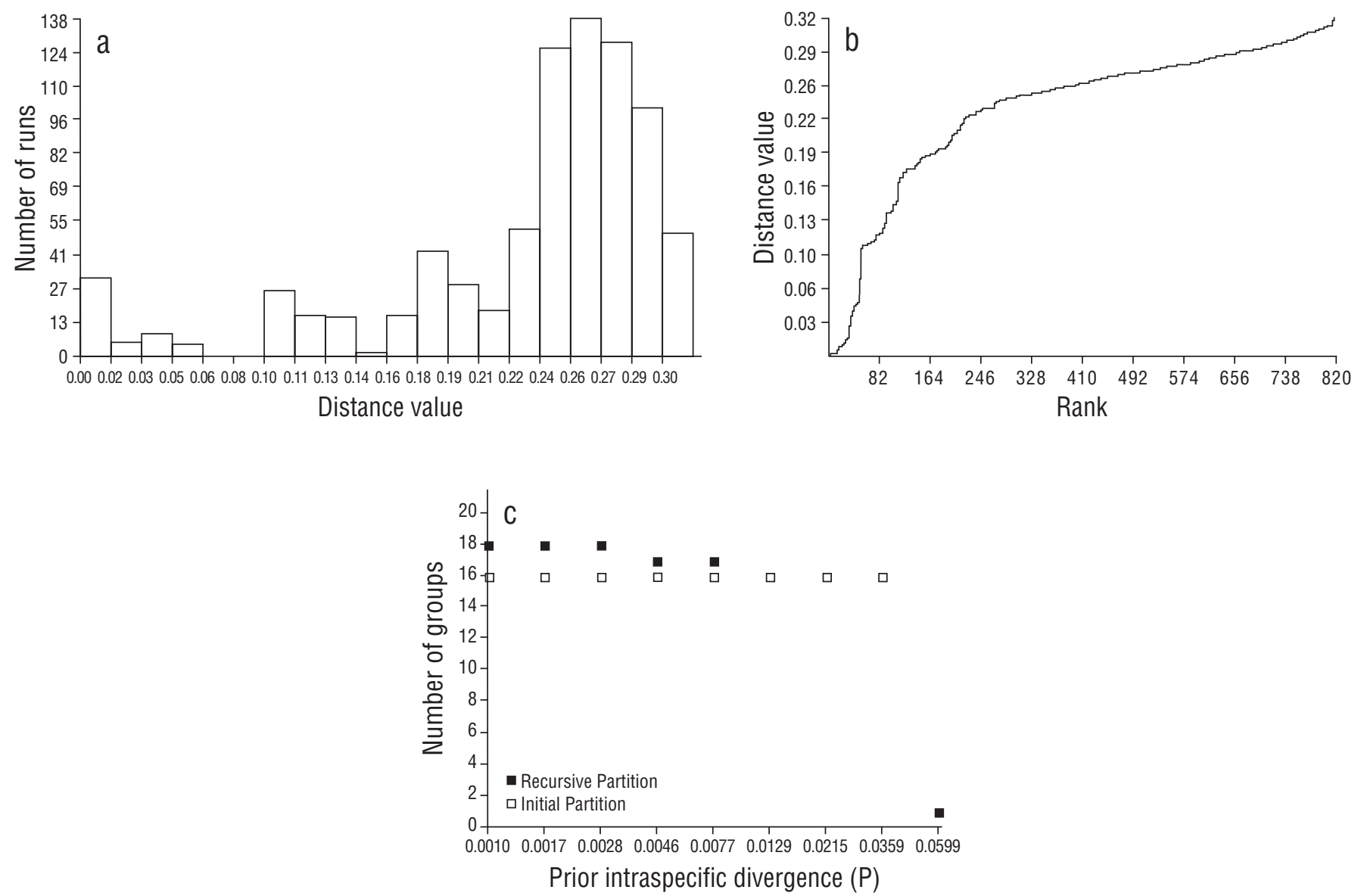

Figure S2. Results of the ABGD analysis using distances based on the K2p model, and the mtDNA dataset. (a) Hypothetical distribution of pairwise differences; (b) ranked pairwise differences; (c) automatic partition of the dataset. The number of groups inside the partitions (initial and recursive) are reported as a function of the prior limit between intra- and interspecies divergence.

Figura S2. Resultados del análisis ABGD utilizando distancias basadas en el modelo K2p, con base en el conjunto de datos de ADN mitocondrial. (a) Distribución hipotética de las diferencias por pares; (b) las diferencias por pares ordenadas; (c) partición automática del conjunto de datos. El número de grupos dentro de las particiones (inicial y recursivo) se identifican en función del límite anterior entre la divergencia intraespecífica e interespecífica. 
Vecchioni et al.: Molecular diversity of the Mediterranean Tigriopus fulvus populations

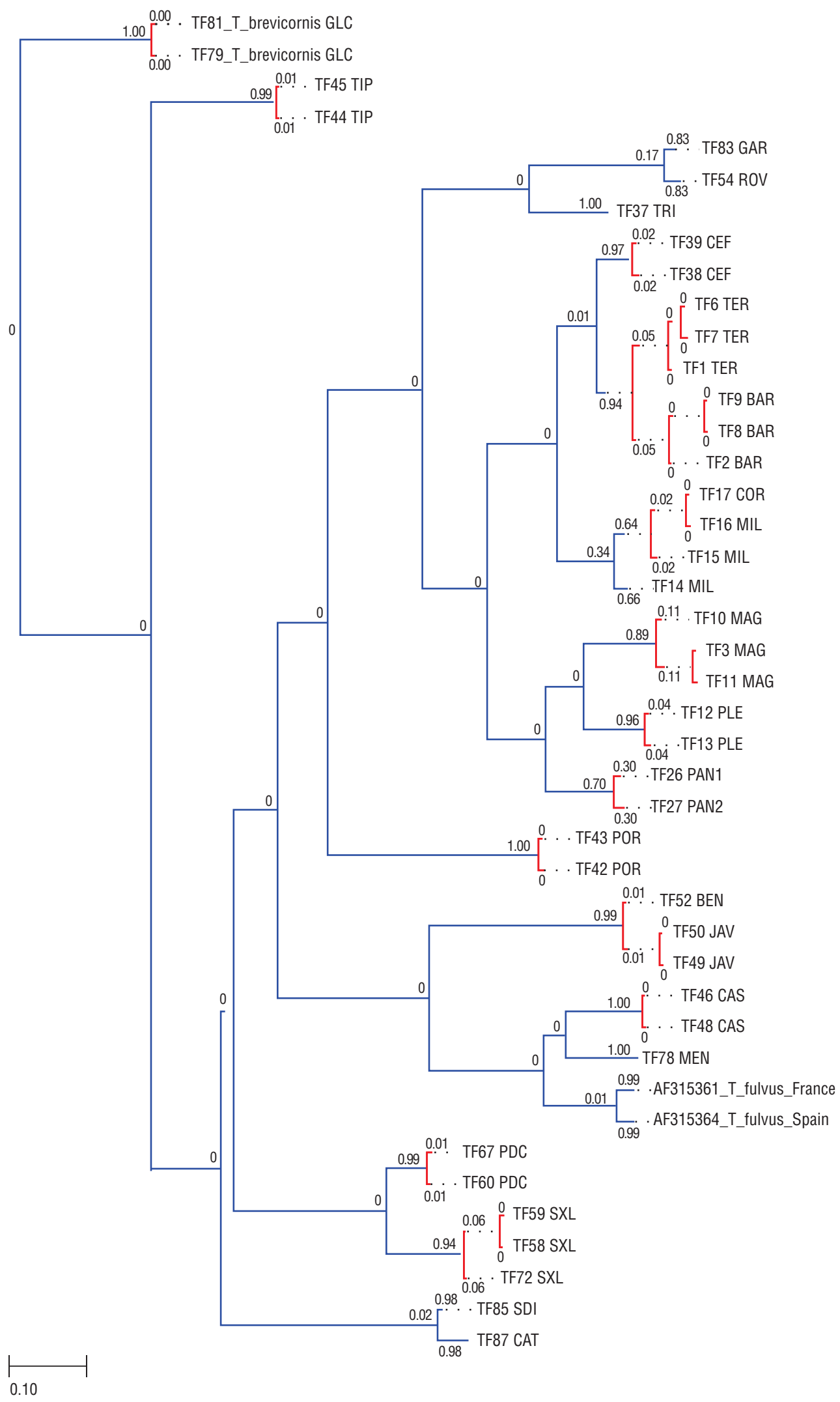

Figure S3. Putative species singled out by the bPTP model. The analyzed specimens are reported using the codes listed in Table 1.

Figura S3. Especies putativas señaladas por el modelo bPTP. Los especímenes analizados se identifican con los códigos que se enumeran en la Tabla 1. 